\title{
RECENT FEDERAL COURT DECISIONS AFFECT- ING STATE LAWS REGULATING FREIGHT AND PASSENGER RATES
}

By Hon. Grant G. Martin, Attorney-General, State of Nebraska.

The trend of railroad management is to get away from state regulations. The Federal Courts are inclined in that direction. The effect of their late decisions is to bestow upon the general government exclusive jurisdiction over all matters, affecting the means, instruments, facilities and rates of transportation companies conducting a business in more than one state. This system would enable the general government to usurp control over local traffic and rob the state of its inherent power to control and regulate its internal commerce and the means and instruments which conduce to the same. So far as transportation companies operating in two or more states are concerned, they necessarily act in a dual capacity and render a dual public service. They perform a service originating and terminating within the state and also a service of an interstate character.

Now the dual character of this public service requires a dual system of regulation, the one subject to the state and the other subject to the nation. While the general government is permitted to reach within the limits of all the states and exercise regulating powers to promote and protect commerce among the states, numerous decisions have committed the Supreme Court of the United States to the proposition that each state has the inherent power to regulate all commerce within its limits of purely an internal character. The state has no right to invade the domain of the Federal government, neither has the latter any right to invade the domain of the state.

In this connection I shall refer to some provisions of the Federal constitution and the early decisions of the Supreme Court of the United States in relation thereto. I do this for the reason that inferior court decisions are tending to Federal regulation rather than state control of public carriers. Section 8 , article $I$, of the Federal constitution provides that Congress shall have power to regulate commerce with foreign nations, and among the several states and with the Indian tribes. 
It does not say that Congress shall have power to regulate commerce in the several states, but among the several states. In discussing the phrase, "among the several states," Chief Justice Marshall said:

"The completely internal commerce of a state, then, may be considered as reserved for the state itself. The internal commerce of a state, that is, the commerce which is wholly confined within its limits, is as much under its control as foreign or interstate commerce is under the control of the general government."

Article 9, of Amendments to Constitution, provides that the enumeration in the constitution of certain rights shall not be construed to deny or disparage others retained by the people.

Article Io, of Amendments to Constitution, provides that the powers not delegated to the United States by the constitution, nor prohibited by it to the states, are reserved to the states respective$1 y$, or to the people.

Article II, of Amendments to Constitution, provides that the judicial power of the United States shall not be construed to extend to any suit in law or equity, commenced or prosecuted against one of the United States by citizens of another state, or by citizens or subjects of any foreign state. The meaning of this amendment is plain. The state of Georgia had been sued in the Supreme Court of the United States by a citizen of another state. The court entertained the action. This decision led to the adoption of the Eleventh Amendment, and its purpose was to prevent the states from being sued by citizens of another state. The Eleventh Amendment is no new thing; it was adopted in 1798.

Our own Nebraska court has held, in an opinion written by Judge Sullivan:

"That the judicial power of the United States does not extend to actions brought by individuals or corporations against a state. The Eleventh Amendment to the federal constitution would be effectually emasculated if it were permissible to enjoin or coerce the agents through which a state performs its corporate functions." (State v.C.R.I. \& P.R.R. Co., 6r Neb. 545.)

Again, our Nebraska court held:

"The circuit court of the United States is without jurisdiction to enjoin a state from the enforcement of its own laws; that which the federal court is without power to do directly it can not accomplish indirectly." (State v. C.R.I.\& P.R. Co., $62 \mathrm{Neb}$. I23.) 
Wherever one, by virtue of his public position under the state government, acts in the name and for the state, and is clothed with her power, his act is her act. Ex parte Virginia, Ioo U. S. 339.)

Seventy years ago the Supreme Court of the United States held that the powers reserved to the several states extend to all the objects which, in the ordinary course of affairs, concern property and the rights of property of individuals, as well as to the internal order, improvement, and prosperity of the state. (King v. American Transportation Co., I Flipp (U. S.) I, I4 Fed. Cas. No. 7, 787.) As late as the I23 U. S. report, the Supreme Court of the United States said:

"The very object and purpose of the Eleventh Amendment was to prevent the indignity of subjecting a state to the coercive process of judicial tribunals at the instance of private parties. It was thought to be neither becoming nor convenient that the several states of the Union, invested with that large residuum of sovereignty which had not been delegated to the United States, should be summoned as defendants to answer the complaints of private persons, whether citizens or aliens, or that the course of their public policy and the administration of their public affairs should be subject to and controlled by the mandates of judicial tribunals without their consent, and in favor of individual interests." (In re Ayers, I23 U. S. 504, date 1887.)

In order to circumvent the purposes of this Eleventh Amendment, public carriers have devised the scheme of having their stockholders begin suit in the Federal Courts against the companies themselves and the attorney-general of the state to enjoin the enforcement of state regulations. This in spirit is an action against the state, because the attorney-general acts only in behalf of the state. Under the state constitution and the laws of the state, he is the law officer of the state. To prevent him from enforcing the laws of the state affecting public carriers, is to stop all machinery of the state government in relation thereto.

In recent years the Federal Courts have gradually broken away from their original holdings referred to and are now committed to the doctrine that a suit against the law officers of the state, who are trying to enforce the laws of the state, is not a suit against the state. These later decisions in effect abrogate the Eleventh Amendment to the constitution.

Under these constructions the Eleventh Amendment serves no useful purpose. The original theory of the Federal constitution 
was that state courts construe state laws in the first instance with the right to review in the Supreme Court of the United States. Under present holdings, many state enactments are enjoined by Federal courts before they are considered by state courts. Thus, the federal courts have become places of refuge for every man or interest who sees fit to assail state enactments. It is true that the federal courts hold that suits against state officers are not suits against the state when such officers are seeking to enforce unconstitutional laws, but this is answered by saying that a Federal court ought to have jurisdiction of the subject-matter of the suit at the time the suit is commenced, and ought not to entertain a suit upon the assumption that state officers are seeking to enforce unconstitutional acts.

The decision in the Minnesota rate case is revolutionary in the extreme. People who comprehend its far-reaching effect upon the rights of the state are astounded. If Congress had brought forth a measure which struck down the right of the states to regulate their internal commerce, every state in the Union would have been aroused.

This decision is revolutionary because it holds that the Minnesota rate reductions, though applying only to commerce within the state, interfere with interstate commerce, and, hence violate the Federal constitution. For over one hundred years, the $\mathrm{Su}$ preme Court of the United States has held that the states had exclusive-control over their internal commerce. During all that time, practically all railroad regulation emanated from the states and not from the general government.

"Rate-making is a legislative function," declares the author of the opinion. What nonsense to say that rate-making is a legislative function, and then proceed as a court to declare every rate so made void for one or all the reasons in the catalogue. What rate fixed by a state legislature has been upheld by a federal court? What is the name of the judge of the Federal, District or Circuit Court who has yet found a legislative-made rate which he has seen fit to uphold? Judge McPherson held that the effect of the Missouri law was to confiscate the property of the railroads. Judge Vandevanter held the same, as to the law of Arkansas. Judge Sanborn, sitting with others, held that the Oklahoma law was taking railroad properties without just compensation, and now reiterates the same thing with reference to the law of Minnesota. 
The facts are, these acts by the legislatures are being struck down as fast as they reach the Federal judiciary. In very recent years, rate reductions in North Dakota, South Dakota, Arkansas, Missouri, Oklahoma, and Minnesota have all met a similar fate. These states constitute an empire in extent and contain a population of over ten million people. Are these people ignorant, malicious, or anarchistic? No, they are intelligent. fair-minded, and patriotic as any people on earth. It is a condition and not a theory that confronts them. These people know and have known for a third of a century that they have been victimized by the public carriers. They know that they have been, and now are, even with the reduced rates in effect, the victims of still extortionate freight rates as compared to adjoining states. These people know, as do all the people of the country, that the railroads have never prospered in their history like they have in the last two years. Yet, in the face of this well known fact, every legislative act designed to prevent extortionate rates has been stricken down by the Federal courts on at least one of two grounds - that it was either non-compensatory or confiscatory. This results from the adoption of an erroneous method of valuing railroad property and of apportioning operating expenses as between state and interstate business.

I am informed that the railway commission of Minnesota spent about $\$ 100,000$ in making a physical valuation of the railroad properties. Every rail and every tie were taken into consideration. The results of this valuation was presented to the referee in the Minnesota cases in the form of evidence. What did he do with it? He brushed it aside and took in its place the testimony of real estate men, introduced by the companies, as to the value of their terminal properties. These real estate men from Minneapolis and St. Paul fixed the values so high that any rate could be proved confiscatory because it would not permit a return based on such valuation. The Circuit Court adopted the findings of this referee and declared him "a master learned in the law." I don't call him that. I want this "master learned in the law" to state the reason why he saw fit to reject the testimony offered by the state based on a large expenditure of state funds in obtaining a physical valuation of Minnesota railroads, and then adopt the testimony of two real estate men brought forth by the railroad companies, which I understand to be a fact. An explanation of why it was necessary to reject the testimony of the state and adopt that 
of the companies on this point would be more helpful and instructive than a repetition of such generalities as the one which reads, "That which is not supreme must yield to that which is supreme." Is it any wonder that the Wall Street Joumal declares that this decision is "invaluable," which means, of course, that it is exceedingly precious?

There is no doubt but that the testimony produced by the Minnesota railroad commission was the fairest and most equitable, concerning the value of railroad properties, which was introduced before the referee who tried the case. This was acknowledged by the greatest authority in America on the subject of railroad construction and maintenance. I refer to Mr. Julius Kruttschnitt, of Chicago. In testifying in the Chicago, Rock Island \& Pacific Railway Company case, on July I2, I9IO, which case is now pending in the Federal Court of this state and involves the validity of our two-cent passenger fare law and the freight rate reduction law, which were passed by the legislature of 1907, this distinguished expert said:

"I have been making a study of this question of railroad valuation for a number of years, and particularly in the last two years, and I have obtained the reports of those state commissions that have valued railroad properties and have studied them, and after looking over all of them it seemed to me that the plan adopted by the Minnesota State Commission was the fairest of any that has been brought to my attention. The plan is contained in a circular, as I remember it, of $\mathrm{Mr}$. Dwight Morgan, who was the expert employed by them to make the valuation, and it seemed to me to be the most comprehensive, most logical, and fairest to both interests of any that I know of. It seemed to me to be particularly free from attack if used in defending railroad suits, because Mrr. Morgan was an employee of a state body and certainly could not be accused by the public of prejudice or partisanship, and I have found very few of his views, if any, that I could not pretty cordially indorse and accept as my own."

These Federal Courts have in part adopted the revenue theory for assigning the value of railroad property in a state to the various classes of business and in apportioning operating expenses. This is a theory sponsored by the railroads, and when fully applied is so vicious in its nature that it enables the companies to defeat any rate established by a state. Had the Minnesota rates been twice as high as fixed by the legislature, still under this revenue theory the companies would have been able to prove them confiscatory. 
With the revenue theory applied in the manner urged by the companies, the state plays a game with the cards stacked, or tries a law suit with the jury packed. To illustrate the viciousness of the revenue theory, let me assume that the entire revenue of one railroad for one year in Nebraska is $\$ 100,000$; of that amount $\$ 20,000$ represents the earnings on the state business and $\$ 80,000$ the earnings on the interstate business. I also assume that the entire operating expenses amount to $\$ 80,000$. Now, the revenue theory, when applied, apportions the operating expenses according to the earnings of state and interstate business. It then follows that $\$ 20,000$ of state revenue is I- 5 of the total $\$ 100,000$ earnings and $\$ 80,000$ interstate is $4-5$ thereof. Now, under the theory, in order to get the amount of operating expenses to be charged to the state business it is necessary to take I-5 of the total operating expenses, to wit, $\$ 80,000$, which is $\$ 16,000$, and $4-5$ thereof, or $\$ 64,000$, represents the interstate. The fallacy inherent in this method is strikingly apparent, because the factors are unequal, the state rates being much higher than the interstate rates.

The vice of the revenue theory is easily perceived when the state rates are increased so as to permit a greater revenue therefrom.

Referring to the illustration above, let me double the state rates so that the revenue therefrom becomes $\$ 40,000$ instead of $\$ 20,000$, and let the interstate rates and the revenue therefrom remain the same. Then $I$ have a total revenue amounting to $\$ 120,000$. Now, I apportion the operating expenses according to the revenue theory. Forty thousand dollars is one-third of the total and $\$ 80,000$, the interstate revenue, is two-thirds. One-third of the operating expenses is $\$ 26,666.66$, and two-thirds is $\$ 53,333.33$, the amount of expenses assigned to the interstate business. Observe that in the first instance the amount of expenses assigned to the interstate business was $\$ 64,000$, whereas now it is only $\$ 53,333 \cdot 33$. The interstate business has gained the neat little sum of $\$ 10,666.66$, the difference between the two. This is accomplished without changing any of the figures in the original illustration, except to double the state rates and thereby secure a larger state revenue. So, if the state rates are multiplied by four, the gain to the interstate becomes more astounding.

This is the "revenue theory," which it is declared "appeals more persuasively to the reason and is the more just and equitable." I 
can not understand how it appeals to the reason of any man. If it is to be characterized as "just and equitable," then I do not understand the meaning of those words when used in that sense. No, this theory does not appeal to the reason. Reason abhors it. Justice and equity condemn it. I have heard of shell games and faro tables, and gaming devices designed to catch their victims coming and going, but I never learned of one which is any more certain of its victim than the "revenue theory" when it is used to its full extent as the basis for establishing a state rate reduction act confiscatory. It will destroy any legislative-made rate. There is no escape, because it is a device which steals away the earnings produced by the state rate and appropriates them to the benefit of the interstate rate.

Instead of characterizing this "reventue theory" as just, equitable, and reasonable, and declaring it the proper method by which to apportion operating expenses as contended for by the railroad companies, I say it is a cold-blooded confidence game, vicious and criminal in its effect upon a people already too long outraged by extortionate railroad rates.

The railroads in Arkansas, Missouri, Oklahoma and Minnesota have successfully resorted to this device. The Circuit Court of Appeals somewhat reluctantly has approved in part this so-called theory, and uses it as a justification for declaring state rates confiscatory and in striking down state acts designed to give the people relief. Is it any wonder that the corporation press from coast to coast hails this decision as "a clear victory for the railroads?" I can not believe that these courts comprehend the results of the revenue theory or realize the disastrous consequences which will inevitably follow its adoption. If they did, this theory would receive their condemnation rather than their approval.

- In the Minnesota case the Court assumes that the rates, both passenger and freight, fixed by the railroads prior to the Minnesota reductions, were lawful rates because the companies had filed their schedules with the interstate commerce commission. The companies have been carrying passengers over this same territory for a third of a century at three cents per mile. During that time the improvement in facilities and equipment have enabled them to lessen the corresponding operating expenses, and in the meanwhile this territory has quadrupled in population. If those rates fixed by the companies thirty years ago were compensatory, what must they now be under present conditions? 
This plea of railroad confiscation is a fiction. It has no basis in fact; it never had. No man is able to call to mind a single illustration of railroad property subjected to anything approaching confiscation. The history of this Union does not afford a single instance of this dire calamity. It belongs to the domain of the imagination. When the property of a railroad company a half mile in length has suffered anything approximating confiscation, it will be time to treat this contention seriously. No good citizen wants to confiscate or even injure the property of another. I do not stand for any policy that will deprive the railroads of reasonable returns upon their investments. This they should have, no more, no less. All $I$ ask is that the method adopted in determining this question shall be fair and just as between the railroads and the people. As the law officer of this state, I protest against the method which some of the Federal Courts have in part approved. It is so palpably unjust and inequitable that I shall condemn and fight it to the end.

Grant G. Martin. 